\title{
The League of Nations, A-Mandates and Minority Rights during the Mandate Period in Iraq $(1920-1932)^{*}$
}

\section{H. Müller-Sommerfeld}

For the new state of Iraq, created after the political end of the Ottoman Empire, 1920 meant the beginning of a "shared history" "with the League of Nations $(\mathrm{LoN})$ and Great Britain. From its twelve years of mandate administration until $193^{2}$ I deal with two issues in this essay. ${ }^{2}$ The first is the different political languages concerning A-Mandates. While the LoN conceived of them as territorial international administration, most Iraqis saw them rather as "colonial rule." The second issue, which I cover in the larger part of the paper, comprises the system of minority protection under the international law of the LoN and its perception in Iraq. In Geneva, it was understood and handled as a legal protection shield for encroachments of nationalist majorities against minorities, but at the same time it was closely linked to the conception of a unitary nationstate, in which minorities should not be entitled to form a state within a state. Iraqi minorities themselves perceived and used these minority rights in different ways, as the contrasting cases of Iraqi Jews and Assyrian Christians show. From the many other minorities in Iraq I consider just these two using new materials from the archive, notably that for Assyrian Christians, of the LoN in the Library of the United Nations Office Geneva (UNOGL).

In this essay I aim to consider the independent role of the LoN in the history of Iraq, and the Middle East, which to date is overshadowed by the

* A draft of this essay was presented at the Lucis conference: Common Ground? Jews, Christians and Muslims in the Middle East, 26-27 September 2013, University of Leiden. For their generous invitation and great hospitality I thank Heleen Murre-van den Berg, Léon Buskens, Daniel J. Schroeter, Petra de Bruijn, Farah Bazzi, Femke Groeneveld, Laura Prak, Tijmen Baarda, and Sasha Goldstein-Sabbah.

1 Frederick Cooper and Ann L. Stoler, "Between Metropole and Colony: Rethinking a Research Agenda," in Tensions of Empire: Colonial Cultures in a Bourgeois World, ed. Frederick Cooper and Ann L. Stoler (Berkeley: University of California Press, 1997), 1-58.

2 Based on my unpublished post-doctoral research on politics and religion during the monarchy in Iraq. 
mandatory power of Great Britain, and France respectively. It seems that the last two moments in the process of silencing the past, described by the Haitian anthropologist and historian Michel-Rolph Trouillot, namely, "the moment of fact retrieval (the making of narratives)" and "the moment of retrospective significance (the making of history in the final instance)" (emphasis in the original), were very effective till this day. ${ }^{3}$

\section{A-Mandates: Different Political Languages}

The LoN came into political existence after World War I as a result of the negotiations between the victorious powers at the Peace conference in Paris from 1919 to $1920 .{ }^{4}$ As the first global inter-governmental organization it set high political goals, as the preamble of the act establishing it, the Covenant from 1919 already reveals:

to promote international co-operation, to achieve international peace and security by the acceptance of obligations not to resort to war, by the prescription of open, just and honourable relations between nations, by the firm establishment of the understandings of international law as the actual rule of conduct among Governments, and by the maintenance of justice and a scrupulous respect for all treaty obligations in the dealings of organised peoples with one another.

Beside this overall idealistic shift in international politics, us president Woodrow Wilson (1913-1921) further imposed in Paris the foundation of mandates as an administrative form against colonial rule and territorial annexations. ${ }^{5}$

3 Silencing the Past: Power and the Production of History, 6th ed. (Boston: Beacon Press, 1995), 26. The first two moments are "fact creation (the making of sources)" and "fact assembly (the making of archives)."

4 At present the best review essay of the vast academic research on the LoN are Susan Pedersen, "Back to the League of Nations," American Historical Review 112, no. 4 (2007): 1091-1117. On chronology, the people involved, and the activities of the LoN, cf. Martyn Housden, The League of Nations and the Organization of Peace (London: Pearson, 2012).

5 At present, we do not have an updated and in depth examination of the origin and complicated elaboration process of mandates at the Paris Conference. Further research should consider the inter-governmental negotiations from 1917 to 1919, the role of non-governmental pressure groups such as the League of Nations Union, and the strong support of the Labour 
Their legal skeleton formed Article 22 of the Covenant of the LoN, which compared to its other articles, is quite long and solemn in tone. Pursuant to this article, mandates were based on the principle "of well-being and development" of the "backward people." This "sacred trust of civilisation"6 was conferred to the Mandatory Powers, but remained under the international control and supervision of the LoN "until such time as they [the indigenous peoples] are able to stand alone." In their conceptual framework mandates were thus foremost a form of international administration as political and economic trusteeships, ${ }^{8}$ a task for government modernization and development aid, and not a "late form of colonialism," 9 as it is widely accepted in research studies on Iraq and the Middle East. The mandate system, termed by the LoN as "a new conception in international law and a novel experiment in colonial

Party. Despite its publication date, the most authoritative study about the mandates is still the comprehensive monograph of the renowned political scientist Quincy Wright, Mandates under the League of Nations (Chicago: University of Chicago Press, 1930 [repr. 1968]). The most recent history emphasizing the African mandates is the two-volume account of Michael Callahan, Mandates and Empire (Brighton: Sussex Academic Press, 1999 [repr. 2008] and $A$ Sacred Trust: The League of Nations and Africa, 2004); in "idem", "Mandated Territories are not Colonies: Britain, France, and Africa in the 1930s," in Imperialism on Trial: International Oversight of Colonial Rule in Historical Perspective, ed. R.M. Douglas, (Lanham, MD: Lexington Books, 2006), 1-20. See Susan Pedersen's new study: The Guardians: The League of Nations and the Crisis of Empire (New York: Oxford University Press, 2015).

6 The French version of article 22 uses "une mission sacrée de civilisation," which from this very beginning shows that the French and British governments had different interpretations of the mandate system and later, in practice, they did not alter from their original perceptions.

7 The total of 11 mandates were later differentiated as A-, B- and C-categories. A-Mandates were Iraq, Palestine/Transjordan, Syria and Lebanon (former Ottoman provinces); B-Mandates were Ruanda-Urundi, Tanganyika, Cameroon, Togoland (largely former German territories); and c-Mandates were German New-Guinea, Nauru, South Pacific and South-West Africa (to be administered as integral portions of the territories of mandatory powers).

8 Carsten Stahn, The Law and Practice of International Territorial Administration: Versailles to Iraq and Beyond, Cambridge Studies in International and Comparative Law (Cambridge: Cambridge University Press, 2008), 73-91; Antony Anghie, "Colonialism and the Birth of International Institutions: Sovereignty, Economy, and the Mandate System of the League of Nations," International Law and Politics 34 (2002): 513-633.

9 Nadine Méouchy and Peter Sluglett (ed.), The British and French Mandates in Comparative Perspectives, Social, Economic and Political Studies of the Middle East and Asia 93 (Leiden: E.J. Brill, 2004), 2. The British and French have largely overshadowed the autonomous presence of the LoN in the Near East. The independent political role of Geneva has been almost forgotten. 
policy,"10 in this region prevented the territorial annexation and introduction of colonial rule after 1918. The policy of "no-annexation" was a guiding principle of us president Wilson at the Paris Peace Conference concerning the former territories of the Ottoman Empire, as he formulated in article 12 of his famous "Fourteen Points" statement before the us Congress in January 1918. Even if Article 22 of the Covenant of the LoN results from a highly complicated editorial process, we must recall that the British Labour Party and the League of Nations Union (Robert Cecil) were deeply involved behind the scenes. For the Labour Party, the anti-colonial orientation of the mandate system as an international form of government was a main political topic on their agenda. ${ }^{11}$ The A-Mandates in the Middle East were thus a historical seam in colonial history, and one must remember that Labour government announced the termination of the British mandates in this region: Ramsay McDonald in Iraq (1924 resp. 1929) and Clement Attlee in Palestine (1947). As an international form of administration on behalf of the LoN, A-Mandates were an aid to state development in the Middle East, and thus an obstacle to the installment of colonial rule over the conquered territories. They forced the governments of Great Britain and France to join the new world order of political self-determination and decolonization after 1918, even if London and Paris did so half-heartedly and each in their own way. There is presently little well-founded research on the functioning of the mandate regime in Iraq in practice over the twelve years. Investigations on the economic aspects would throw new light and thus bring about a rethinking of the mandates. They were precursors of decolonization and set up the more comprehensive developments that followed after the end of World War II. It seems, however, that the label "colonial past" in the Middle East fits more ideologically, since it confirms the dominant political opinion of

$10 \quad$ LoN, Ten Years of World-Cooperation (Geneva: League of Nations, 1930), 330.

11 Henry R. Winkler, "The League of Nations Movement in Great Britain 1914-1919," Rutgers University Studies in History 7 (New Brunswick, NJ: Rutgers University Press 1952, [repr. 1967]); in "idem", "The Development of the League of Nations Idea in Great Britain 19141919," The Journal of Modern History 20, no. 2 (1948): 95-112. This article, which is more than sixty years old, proves that thorough research on the elaboration of the Mandate system at the Paris Peace Conference is needed, especially as complex correlations were never analyzed in depth. Somehow, this topic escapes research and historiography. Helen McCarthy did not include Mandates in her dissertation which is published under the title The British People and the League of Nations: Democracy, Citizenship and Internationalism, c. 1918-45 (Manchester: Manchester University Press, 2011). Stephen Howe, in his in-depth and recommended study Anticolonialism in British Politics: The Left and the End of Empire, 1918-1964 (Oxford: Oxford University Press, 1993), omits a wider consideration of the Mandates. 
imperial exploitation through the "West," dividing "properly" the good and bad actors. Even if the B- and C-Mandates did not directly effect colonial rule, the mandate system generally required that colonial powers discuss and rethink the character and legitimacy of that rule. ${ }^{12}$

The trusteeship-conception of the mandates never spread widely in Iraq, and not only because of its complete novelty. It was probably due to the fact that British forces militarily conquered the three Ottoman provinces of Basra, Baghdad, and Mosul from 1914 to 1918. In 1920, the status of military occupation was transformed, in Europe, into the mandatory regime, which at this time only existed in the form of Article 22 of the Covenant of the LoN, and had yet to be worked out in Geneva. The de facto beginning of the mandate regime in Iraq was delayed by the de jure Ottoman status of the territory. This came to end after the signing of the Lausanne Treaty in July 1923 and the recognition of the border line between Turkey and Iraq in December 1925, when Turkey renounced her territorial rights over the province of Mosul, which is discussed below.

Another important factor for the non-acceptance, misunderstandings, and extraordinary aversion for the term "Mandate" in Iraq - it was generally omitted from official documents - was the widespread international doctrine of national political self-determination before the end of World War I. In January 1918 us President Woodrow Wilson proclaimed this formula as one of his famous 14 points for the new world order. ${ }^{13}$ For a great part of the Middle Eastern population, though not the whole, this promise nourished strong hopes for political independence. But they obtained instead the constitutionally sophisticated mandates; even politicians did not know exactly what they were or should be. Given the British and French status as conquerors in the Middle East, the possibility that the mandates would be equated with the wellknown colonial rule was therefore quite likely. Political propaganda was probably also at work: in 1919 Vladimir I. Lenin, head of government of the Russian SFSR (1917-1924), termed the mandates a "fig-leaf" for colonialism. ${ }^{14}$ Sir Percy

12 Susan Pedersen, "The Meaning of the Mandates System: An Argument," Geschichte und Gesellschaft 32, no. 4 (2006): 560-582.

13 As recently shown, this brilliant formula was found by Vladimir I. Lenin. The communists in Russia dealt with it extensively long before Wilson and other politicians in western states addressed it. The latter adopted this political slogan because of its great popularity and widespread appeal in the eastern countries of Europe. Jörg Fisch, Das Selbstbestimmungsrecht der Völker. Die Domestizierung einer Illusion (Munich: Beck, 2010), 151-154.

14 Address to the Second All-Russia Congress of Communist Organizations of the Peoples of the East, 22 November 1919: "And when they talk of handing out mandates for colonies, we 
Cox, the first British High Commissioner for Iraq (1920-1923), assumed that this colonial understanding of mandates was due to a bad translation of the term mandate into Arabic, or incorrect renderings in the Arabic press, after the mandate idea became known in Paris. ${ }^{15}$ Nationalistic circles in Iraq, a great number of Iraqi politicians, as well as the Muslim population and its religious scholars, all remained unenthusiastic about the mandate right up until its end in 1932. For most of them, Great Britain was a political sovereign, first of an infidel Christian government and second, a mandatory power with limited political authority. Thus, the political language of most Iraqi politicians, the population, and the LoN were divided by a deep gulf that was never crossed, rather it remained a permanent gap in what should have been common ground.

\section{System of Minority Protection of the League of Nations}

In the development of minority rights under international law, the Paris Peace Conference of 1919-1920 represented a historic climax. ${ }^{16}$ In those heydays of nationalism minority rights were considered a necessary legal protection against the political and cultural majorities that were created by the new political borders in central and eastern Europe. The new nation-states created after the disintegration of the defeated multinational and multi-religious Prussian, Austrian-Hungarian, and Ottoman Empires in World War I thus had to sign treaties or make declarations with special provisions for the protection of minorities. ${ }^{17}$ For them, these were a necessary part of becoming a member of the LoN, and this meant their international recognition.

know very well that it means handing out mandates for spoliation and plunder-handing out to an insignificant section of the world's population the right to exploit the majority of the population of the globe." Lenin, Collected Works, trans. George Hanna (Moscow: Foreign Language Publishing House, 1965), 30:151-162.

15 The Letters of Gertrude Bell, vol. 2 (1927 [repr. Teddington, 2006]), 87-88.

16 From the vast legal literature, cf. Péter Kovács, The Protection of Minorities under the Auspices of the League of Nations, in The Oxford Handbook of International Human Rights Law, ed. Dinah Shelton (Oxford: Oxford University Press, 2013), 325-344; Li-ann Thio, Managing Babel: The International Legal Protection of Minorities in the Twentieth Century, International Studies in Human Rights 81 (Leiden: Nijhoff, 2005), 27-98.

17 In total, fifteen agreements of this type were concluded in Paris on the "model" of the Minorities Treaty between the Principal Allied and Associated Powers and Poland, signed at Versailles, on 28 June 1919. Other treaties were for example: Treaty of Peace between the Allied and Associated Powers and Austria, 10 September 1919 (Part III Section V Arts. 62-69); Treaty of Peace between the Allied and Associated Powers and Bulgaria, 
The LoN developed the first and to date the only system of minority protection under international law. It brought together the forerunners of religious and national protection rights into the triadic concept of "racial, religious, and linguistic protection."18 It was based on the principle of equality before the law and pledged for minorities the same civil and political rights the majorities had, and conferred them additional special cultural and religious rights such as the freedom of religion and worship; self-administration and self-organization, including the right to own charitable organizations, social institutions, schools, etc.; and the right to use minority languages in schools and the public domain.

Two aspects were essentially new for this advanced system of minority protection, which should be understood as well as legal positive discrimination. First, its placement "under the guarantee of the LoN,"19 which before was vested into the Great Powers and often gave them the opportunity to interfere in the internal constitution of other states. "Under the guarantee of the LoN" meant that the legal provisions could not be modified without consent from Geneva, that any member of the Council of the LoN was entitled to call attention to any infraction or even a danger of infraction of minority rights, that the Council may thereupon take such action as it deems appropriate. The second aspect consisted in granting a special right for minorities to submit petitions with grievances to the LoN, if they considered that their rights were violated by their governments. ${ }^{20}$

This protection of racial, religious, and linguistic minorities under international law was also central to A-Mandates. In Iraq, it was implemented with the

27 November 1919 (Part III Section IV. Arts 49-57), Treaty of Peace between the Allied and Associated Powers and Hungary, 4 June 1920 (Part II Section vi Arts 54-60); Treaty of Peace between the Allied and Associated Powers with Turkey, 24 July 1923 (Part I Section III Arts 37-45). Cf. Carole Fink, The Minorities Question at the Peace Conference, in The Treaty of Versailles: A Reassessment after 75 Years, ed. Manfred Boemeke, Publications of the German Historical Institute (Washington: German Historical Institute, 1998), 249274 .

18 All relevant documents from 1920 to 1930 are compiled in LoN, Protection of Linguistic, Racial or Religious Minorities by the League of Nations. Resolutions and Extracts from the Minutes of the Council, Resolutions and Reports adopted by the Assembly, relating to the Procedure to be followed in questions Concerning the Protection of Minorities, C.8.M.5.1931.I, Geneva $^{2} 1931$.

19 The legal basis was Article 12 of the Polish Treaty of 1919, which was identical in all minority agreements.

20 Martin Scheuermann, Minderheitenschutz contra Konfliktverhütung? Die Minderheitenpolitik des Völkerbundes in den zwanziger Jahren, Materialien und Studien zur Ostmitteleuropa-Forschung 6 (Marburg/Lahn: Herder Institute, 2000). 
legal system under constitutional law ${ }^{21}$ and again confirmed by the Iraqi Declaration of Guarantees to the Council of the LoN from May 1932, to which I refer later.

For the officially recognized Iraqi religious minorities these minority rights, which grew out of western European politics and thought, did not bring about any radical change on the ground. They did not abolish, but continued their Ottoman millet-system, last amended by the reform edict of the Sublime Porte in February 1856 ( hatt-i hümayun). This pertains especially to the maintenance of their self-organization and administration and their own religious jurisdiction and courts, which were anachronistic when compared to the otherwise modern judicial system introduced in Iraq. It seems as if the LoN and Great Britain were not as brave as Mustafa Kemal (Atatürk) and his government in Turkey in the 1920s, when they radically abolished the traditional religious infrastructure of minorities, even though other problems were created in this process. ${ }^{22}$

However, Iraqi minorities perceived the minority protection under international law very differently. The leaders of the Jewish community rejected them entirely, on the grounds of their identification as Arabs, and therefore already an integral part of the new Iraqi state and society; for this reason the Jews refused any special treatment. By contrast, for the religious and ethnic minorities who had not been officially recognized, the special protection rights offered a historic chance for their societal and communal transition into the new political age. This was particularly true for Assyrian Christians, Baha'is, and Kurds, all of whom made extensive use of them.

\section{IraqiJews}

The history of Iraqi Jewry and the minority rights of the LoN can be told quickly. A month after the British military conquest of Mosul, in November 1918, fiftyeight prominent Baghdadi Jews came as political-economic representatives of the three mostly urban communities of Baghdad, Mosul, and Basra, and peti-

21 Article 3 of the Treaty of Alliance between Great Britain and Iraq, signed at Bagdad, 10 October 1922 (Cmd. 2370 Treaty Series No. 17 [1925]); Articles 6, 12, 13, 16, 18, 69, 73, 75, 78, $79,80,112$ in the Constitution of 1925 .

22 The most serious result was that the recognized religious minorities lost their status as legal entities. Their leaders could no longer operate as official representatives of their communities to address their needs and interests to the government on a legal basis. They were not able to conduct their own businesses, for example, to sell properties. Thus, their dependence on state authorities was increased and reached a critical point when the appointment of a new chief rabbi or patriarch was needed. 
tioned the British Acting Civil Commissioner Arnold T. Wilson (1918-1920). They asked for the preservation of the "free opportunity for economic and educational development"; these they believed to be the main pillars that would guarantee their history and communal life in the country. The petitioners asked for British citizenship, since they mistrusted the ruling political and administrative abilities of local politicians and inhabitants. But their main concern with such a local government was its "very strong theocratical character due to the dominance of religious feelings which are unreconcilable with the idea of giving to alien confessions any sort of privilege or rights." ${ }^{23}$ Therefore, at the end of 1918 Jewish representatives voted in the referendum for direct British administration. ${ }^{24}$ Later, the mandate regime fulfilled their expectation in part, since it meant a dual governmental organization: a British administration and Arab government, with King Fayșal I as its head (1921-1933). Nevertheless, Iraqi Jews remained loyal citizens, they identified themselves with the new body politic, and their representatives worked closely with the government. This attitude was not only because of strategic reasons, which minorities must always bear in mind, but also because of their identification and self-understanding as part of the Arabic culture and history of the country. ${ }^{25}$

Essentially, the communal aim of Iraqi Jewry after 1920 was integration and not segregation from the new social and political fabric. Although their doubts about Arab political rule never changed fundamentally, their representatives continued to oppose steps to obtain recognition as a national minority. In view of the termination of the mandate regime in 1932, the far-sighted statesman Sasun Hisqail (1860-1932), member of the Iraqi delegation to Geneva, once more emphasized before the LoN that Iraqi Jews consider themselves as Iraqis and therefore do not need special minority rights. ${ }^{26}$ It should be mentioned that at this time several international Jewish organizations, such as the Joint

23 "The Jews of Baghdad Petition for British Citizenship at the End of World War I," published in The Jews of Arab Lands in Modern Times, ed. Norman A. Stillman (Philadelphia: Jewish Publication Society, 1991), 256-258.

$24 \mathrm{~L} / \mathrm{P} \& \mathrm{~s} / 10 / 755$, Self Determination in Iraq, English Text, Febr. 1919/Arabic Text, May 1919, 24.26/ Decl. No. 13 (5)-Baghdad; Decl. No. 14 (3)-Musul, in Iraq Administration Reports 19141932, vol. 3, ed. Robert L. Jarman (Slough: Archive Editions, 1992), 26.28. 61.67.

25 Orit Bashkin, New Babylonians: A History of Jews in Modern Iraq (Stanford, CA: Stanford University Press, 2012), 1-57.

26 AIR 23/806, Secret Report. Appendix A The Jews of Iraq, gth July 1934, in Records of Iraq, 1914-1966, vol. 7, ed. Alan de L. Rush and Jane Priestland (Slough: Archive Editions, 2001), 630. S. Hisqail was a member of the Ottoman parliament (1908-1918), minister of finance in Iraq (1920-1925), and Baghdad deputy to the parliament. 
Foreign Committee, ${ }^{27}$ the Alliance Israélite Universelle, and the American Jewish Committee refrained from intervening on behalf of Iraqi Jews at the international level and respected the rejection by Iraqi Jews of minority rights. ${ }^{28}$ Concerning the years after the establishment of the state of Israel in 1948, there were no traces of this reluctance.

\section{Assyrian Christians ${ }^{29}$}

In the broad spectrum of oriental Christianity, Assyrian Christians represent a singular ecclesiastical tradition because of their dyophysite Christology, which distinguishes them from other oriental Christians. With a history dating back more than 1,500 years, this ancient Syriac-tradition was widespread from Mesopotamia to India. At its height, the Holy Apostolic Catholic Assyrian Church of the East, as it is known today, numbered several million. After the Mongol invasions and devastations in the Middle East, the Church of the East never regained its previous greatness. Its members retreated to mountainous areas in northern Mesopotamia, northwest Iran, and southeastern Turkey, where they merged into a tribal confederation. Under this status, Assyrian Christians entered the new political order of nation-states after World War I. For them, minority protection rights became, over the years, an important argument in their long struggle against their communal integration into the Iraqi state and society. The main aim for the patriarchal family and most of the tribes, especially for the leading Tiyari and Tkhuma from the Hakkari region (so-called "mountaineers"), today in Turkey, was to preserve their traditional tribal identity, organization, and religious-political order with the Catholicos as spiritual and temporal leader. Assyrian Christians fought a fierce battle on the national and international levels; this lasted until 1948, when Catholicos Mar Shimun Eshai (1908-1975) finally advised his flock in Iraq to integrate as loyal citizens. ${ }^{30}$

Even though the issue of minority rights for Assyrian Christians reached its climax after the period considered here, the events between 1920 and $193^{2}$ cannot be easily summarized, as in the case of Iraqi Jews, because archival

27 UNOGL, LoN Archives, s345/No. 2/28-33, Iraq Minorities: The Joint Foreign Committee was a merger of the Board of Deputies of British Jews and Anglo-Jewish Association and addressed foreign matters.

28 American Jewish Committee, "Meeting of the Executive Committee," 14 February 1932, Rights of Minorities in Iraq, available online: www.ajcarchives.org, accessed January 2014.

29 For the sake of historical accuracy I use this term, though the term "Assyrians" is more widespread in the literature.

30 Letter to Mar Khnanisho, 9 August 1948, in Light from the East Published by the Patriarchal Council, Inc. of the Church of the East. A Collection of 27 Issues from 1948 to 1954, 1.1 (1948), 7. 
and other newly published sources compel us to examine other perspectives than those usually presented in the official historiography of Assyrian Christians.

After 1920 Assyrian Christians in Iraq were in quite a different situation than that of Iraqi Jews, not just because of their tribal constitution and tough, almost militant identity. After the barbarities of the Ottomans and Kurds at the beginning of World War I, most Assyrian Christians fled from southeast Turkey (Hakkari) to northwest Iran, since Christians were generally considered traitors in Turkey. Furthermore, because of moving battle fronts after the end of 1917 and their unsuccessful rebellion against the Turks, most Assyrian Christians ended up trekking southward to the British occupied zone in Mesopotamia. ${ }^{31}$ Starvation and cold on these long dramatic flights of approximately 47,000 persons $^{32}$ caused several thousand deaths and further decimated the ancient Apostolic Church of the East (ACE), even beyond the traumatic massacres at the hands of the Ottomans and Kurds during and following $1915 .{ }^{33}$

The vast majority of Assyrian Christians in Iraq were thus refugees, with the exception of smaller tribes in the Barwari region (in the Dohuk governorate, Mosul province), who had lived there from ancient times. Until 1921 they found shelter in the British camps in Ba'quba near Baghdad and afterwards in Mandan, east of Mosul. ${ }^{34}$ From the outset, their primary aim was to return to their mountain homes, which were now in Turkish and Iranian territory, but various schemes on their account proved unsuccessful, as the Turkish and Iranian governments rejected the refugee policy.

31 See the eyewitness account in An Assyrian Odyssey Covering the Journey of Kasha Yacoub Yauvre and his Wife Mourassa from Urmia to the Court of Queen Victoria 1879-1881 and The Exodus of Assyrians from their Ancestral Home 1918, comp. and annot. by Youel A. Baaba (Alamo: Youel A. Baaba Library, ${ }^{2} 2000$ ), $81-132$. See also Joel E. Werda, The Flickering Light of Asia, or the Assyrian Nation and Church (Chicago, 1924 [repr. 1990, 2011]), 6o ff.; Mohammad Gh. Majd, Persia in World War I and its Conquest by Great Britain (Lanham, MD: University Press of America, 2003), 209-218, 243-250.

32 Unofficial figure in L'Asie Française 174 (Oct. 1918-Jan. 1919), 158.

33 Hannibal Travis, Genocide in the Middle East: The Ottoman Empire, Iraq, and Sudan (Durham: Carolina Academic Press, 2010), 237-276; Sébastien de Courtois, The Forgotten Genocide: Eastern Christians, the Last Arameans, trans. Vincent Aurora (Piscataway: Gorgias Press, 2004).

34 In October 1919 they numbered 24,579 persons. (Office of the Civil Commissioner, "Memoranda on the Armenian and Assyrian Refugees at present in Camp Ba'qūba Mesopotamia," Baghdad 1919). For a detailed presentation see also Herbert H. Austin, The Baqubah Refugee Camp: An Account of Work on Behalf of the Persecuted Assyrian Christians (London, 1920 [repr. 2006]). 
Beside these external dire straits, Assyrian Christians were also internally weakened, due to leadership rivalries at the ecclesiastical and the secular/political level. They were unsettled until the mid-1920s. In May 1920 the sick Catholicos Mar Shimun Paulus died in Ba'quba and Mar Shimun Eshai, who was 12 at the time, was consecrated one month later as his successor. This triggered the vehement protest of the Mar Abimalek Timotheos from Trichur/India (18781945), who felt he should be involved as a high ranking ecclesiastical figure. ${ }^{35}$ The conflict was solved when Mar Abimelek Timotheos was named as regent of Mar Shimun Eshai until his coming of age. At the secular/political level, General Agha Petros (1880-1932) was a main actor in the battle for the political cause of the Assyrian Christians, who sought autonomy, and failing that, a semi-independent status in the corner of the three countries of Iraq, Turkey, and Iran. ${ }^{36}$ In addition, several Assyrian Christians from around the world petitioned the relevant politicians, beginning at the Paris Peace Conference in 19191920 and continuing until the Conference of Lausanne in 1922-1923. ${ }^{37}$

Lady Surma (1883-1975), aunt of the new Catholicos, was a crucial longtime player in charge of the secular/political affairs of the ACE. ${ }^{38}$ Allied with her brother David d'Mar Shimun (1889-1974), father of Mar Shimun Eshai and commander of the Assyrian Levies, she fought unwaveringly to secure the ancient religious-political identity and order of the ACE in the new world of nation states; for most Assyrian Christians, living under Arab rule was unimaginable. When faced with the reduction of the mandate regime in Iraq from twenty to four years in April 1923, ${ }^{39}$ they were deeply upset. Lady Surma reported to

35 The official version presents Theodore d' Mar Shimun, The History of the Patriarchal Succession of the D'Mar Shimun Family (Mar Shimun Foundation ${ }^{2} 2008$ ), 97-101. Related to the protest of Mar Timotheos Abimalek see Mar Aprem Mooken, The History of the Assyrian Church of the East in the Twentieth Century with Special reference to the Syrian Literature in Kerala (Kottayam: St. Ephrem Ecumenical Research Institute, 2003), 138-142.

36 He worked together with the British government in London, with Sir Percy Cox in Iraq, and with the French and Turkish government. The biography and role of Agha Petros in the history of the ACE still remain to be written.

37 Joseph Yacoub, La Question Assyro-Chaldéenne, les Puissances Européennes et la Société des Nations (19o8-1938) (Lyon: University of Lyon II, 1984), 1:91-126, 135-181.

38 For a rather hagiographic presentation, see Claire Weibel Yacoub, Surma l'Assyro-chaldéenne (1883-1975) dans la tourmente de Mésopotamie, Peuples et cultures de l'Orient (Paris: Harmattan, 2007).

39 The Treaty of Alliance with Iraq of October 1922 stirred up fierce debates in Great Britain, e.g., in the House of Commons on 20 February 1923 (HC, Deb 20 Febr. 1923, vol. 161 cc2399-2471, also available online Hansard 1803-2005 http://hansard.millbanksystems .com/, accessed February 2014). As a result, the new British-Iraqi Protocol of the 3oth 
William A. Wigram (1872-1953), former head of the mission of the Archbishop of Canterbury to the Assyrian Christians and a longstanding supporter of the ACE, about their petition to Sir Henry Dobbs, the British High Commissioner for Iraq (1923-1928). She summarized their situation and claims as follows:

In July 3rd (os) we had a meeting here in Bebaydi of the Assyrian chiefs and Bishops, to discuss their future, in case, that British did leave 'Iraq after 4 years. To go under Turkey again is out of the question with them all; as to their relations with Arab Governments, they are willing (as long the British Government remains in Iraq, and are allied with them) to work with and be in harmony with them; but all their doings to go through British officials. The Assyrians are very unwilling to put themselves direct under Arab Government. ${ }^{40}$

In addition to the known anti-Arab/Islamic feelings and identity of the leading Assyrian Christians, their claim for political autonomy was based on three pillars. The first was the British "promise" of political support for an "Assyrian homeland" (a promise which remained unproven and unconfirmed despite British archival investigations), on the basis of their alliance with Great Britain in World War I. ${ }^{41}$ Despite this conflict, the British government was an indirect supporter of the ACE through the Assyrian levies. This military unit offered the only stable source of income for Assyrian Christians in Iraq. The second pillar of their anti-Arab position was their awareness of the inter-church aid of the Archbishop of Canterbury and other Anglican clerics, which Lady Surma established anew with her visit to London in 1920, though their Catholicos had denounced it in the 1910s. Later, when the patriarchal family realized that they would not receive any support in their political aims from the British, the minority rights of the LoN became the third pillar. Mar Shimun Eshai in

of April, 1923 was concluded; this reduced the Mandate term to four years (Cmd. 2120, London 1924).

AIR 23/449, "The Residency Baghdad 4th August 1923 to Lady Surma Mar Shimun," in Minorities in the Middle East: Christian Minorities 1838-1967. Assyrian Communities in the Levant and Iraq, Part I, 1880-1938, vol. 7, ed. Bejtullah D. Destani (Slough: Archive Editions, 2007), 208.

41 This later became the British "betrayal," very firmly pronounced in The Assyrian Tragedy (Annemasse: Granchamp, 1934 [repr. 2010]) and Yusuf Malik, The British Betrayal of the Assyrians (Chicago: Assyrian National Federation, 1935). The British side presents John Fisher, "Man on the Spot: Captain George Gracey and British Policy towards the Assyrians, 1917-45," Middle Eastern Studies 44, no. 2 (2008): 215-235. 
particular used these rights as a last straw and weapon to achieve his goal of maintaining his position as Catholicos (religious and temporal head of the ACE).

A crucial date for the history of Assyrian Christians in Iraq was the recognition of the border line between Turkey and Iraq in December 1925. This decision nullified their hopes of recovering their former homes in Hakkari, since this region remained part of Turkey and its government categorically refused to resettle any Assyrian Christians on Turkish soil. ${ }^{42}$

Before turning to events after December 1925, let us look first at the inquiry of the frontier commission of the LoN in Mosul at the beginning of 1925, as this inquiry was important in several respects. Turkey and Great Britain quarreled about the location of the border between Turkey and Iraq from the end of 1918. Ankara insisted that Mosul province be a legal part of Turkey and thus that the southern line of the province be the border to Iraq. London believed that because the territory had already been conquered the northern line of the province should be its border. As expected, their bilateral negotiations failed, and the Mosul dispute was brought before the LoN. What followed was one of the LoN's most prominent successful arbitration cases in its history-for Great Britain and Iraq, but not for Turkey ${ }^{43}$ The inquiry of the frontier commission in Iraq in 1925 was part of this mediation procedure in Geneva, but it was also a further touchstone for the LoN's system of minority protection in the Middle East. Though to date it has not been explored deeply, ${ }^{44}$ we can say that it was a multi-dimensional clash of political and cultural differences-a dialogue of the deaf and mute, between the "civilized world" and "backward people."

In application of the principle of political self-determination and minority protection, the frontier commission of the LoN had a threefold task. First, to

42 John Joseph, The Modern Assyrians of the Middle East: Encounters with Western Christian Missions, Archaeologists, and Colonial Powers, Studies in Christian Mission 26 (Leiden: E.J. Brill, 2000), 175-185.

43 From current research studies, see Aryo Makko, "Arbitrator in a World of Wars. The League of Nations and the Mosul Dispute, 1924-1925," Diplomacy \& Statecraft 21, no. 4 (2010): 631649; Sarah Shields, "Mosul, the Ottoman Legacy and the League of Nations," International Journal of Contemporary Iraqi Studies 3, no. 2 (2009): 217-230; Stephen J. Stillwell, AngloTurkish Relations in the Interwar Era, Studies in British History 73 (Lewiston, NY: Mellen, 2003), 67-120; Mesut Özcan, "Border Concept and Turkey-Iraq Border," Turkish Review of Middle East Studies 13 (2002): 41-85. See also Joseph Yacoub, La Question, 2:245-273.

44 Péter Kovács, "Paul Teleki et le réglement de l'affaire de Mossoul dans la Société des Nations," Miskolc Journal of International Law 1, no. 2 (2004): 156-187; István Klinghammer and Gábor Gercsák, "Der ungarische Geograph Pál Teleki als Mitglied der MossulKommission," Cartographica Helvetica 19 (1999): 17-25. 
hear the three parties in conflict: the governments of Turkey, Great Britain, and Iraq; second, to collect data and information about the conflict; and third, to determine the wishes of the population directly concerned, on the question of whether the province of Mosul should be part of Turkey or Iraq. Its members were the Swedish diplomat and head of the commission Carl Einar af Wirsén (1879-1946), the geographer and former prime minister of Hungary Pál Teleki (1879-1941), and the Belgian officer Albert Paulis (1875-1933). They spent almost three months from January to March 1925 in Iraq in the company of British, Iraqi, and Turkish advisors. But since their main commitment was to the principles of impartiality and the formation of independent opinions, they were eager to demonstrate their independence, and especially feared the domination and influence of British officials, which were well known in Geneva. On this ground, the LoN troika planned, for example, to go alone and in secret to the destinations in the more rural areas of the Mosul region. After intense discussions they heeded British advice and used military escorts. Despite difficult odds the officials from Geneva managed to consult a large part of the population in the province of Mosul; and determined at the end that a majority favored political affiliation to the Iraqi state.

The hearing of tribal leaders (maliks) and chiefs of the Assyrian Christians ${ }^{45}$ took place on 7 February 1925. A few days later they submitted a petition to the troika asking for a direct LoN mandate for their homelands, and failing that, a British protectorate. If their territories were to come under Turkish or Iraqi sovereignty, nothing would remain for them but emigration. ${ }^{46}$ We cannot ignore the fact that Assyrian Christians clearly expressed their unwillingness to live under Arab-Iraqi or Turkish governance. This aspect, and not persistent persecution or "Islamic oppression" as their historiography would have us believe, should be seen as the main characteristic of their history in these years.

In its final report, the frontier commission considered a variety of solutions for the disputed territory. Without the presence of the mandatory power it would be better for Mosul province to belong to Turkey, since Turkey's political situation was more stable than that of Iraq. The partition of the Mosul

45 The commission estimated their total number around 25,000. Of these, 5,00o were from Persia, 14,00o were in the Mosul province, and 6,00o were from the Hakkari region. LoN, C.400.M.147.1925.VII, Question de la frontière entre la Turquie et l'Irak. Rapport présente au Conseil par la Commission constituée en vertu de la résolution du 30 septembre 1924/Question of the Frontier between Turkey and Iraq. Report submitted to the Council by the Commission instituted by the Council Resolution of September 3oth, 1924, 16th July 1925, 5-90, here 82.

46 UNOGL, LoN Archives, S14/D19, Assyriens. 
province on racial considerations was not recommended because the population was ethnically intermingled. ${ }^{47}$ Finally, they favored the "Brussels" line; that is, if this was to be the final border and the province of Mosul was to belong to Iraq, then the prolongation of the mandate of the LoN-actually lasting until 1927-would be indispensable, at least for twenty-five years. The commission advised that special regard should be paid to the establishment of a Kurdish administration, that a representative of the LoN should be appointed to smooth out complaints and grievances of the minorities on the ground, and special measures should be taken for these minorities, such as assurances of religious freedom and the establishment of their own schools. Assyrian Christians should have a certain local autonomy with its own officials. Eventually, in the process of its practical implementation, most of these recommendations were skipped.

After further tough negotiations in Geneva, on 16 December 1925 the "Brussels" line was ultimately declared as the border between Iraq and Turkey. The British efforts to recover the Hakkari region for the Assyrian Christians were unsuccessful; they were now unequivocally under Turkish sovereignty. On this basis and according to the wishes expressed before the frontier commission, the leaders of the Assyrian Christians petitioned Sir Henry Dobbs on 14 February 1926. Since this petition, written in English and modern Syriac, is mostly unknown, I quote a long passage:

But on the 17th December 1925 we learned that the League of Nations declared Mosul for Iraq under the British Mandate with its temporary boundary, and that our land was to remain in the Turkish Territories, ${ }^{48}$ [so by learning this] our hopes were frustrated. While this is fact, now our mind is not changed and our requests are the same first one which has been submitted to your Excellency, i.e. either our small lands under the British Mandate, to be returned at any possible way, if not, we beg to immegrate us to any of the British Colonies were [where] the climate and water would suit us, and [where] we would be relieved from our

47 LoN, C.400.M.147.1925.VII, Question, 87.

48 This refutes J. Joseph's assertion that the decision of the LoN was not communicated to the Assyrian Christians, most probably because it was suppressed by the mandatory government (Modern Assyrians, 185). It would be interesting to know how Assyrian Christians in Iraq indeed learned just one (!) day after the official decision in Geneva. Joseph further states, incorrectly: "Not aware that their settlement claims had been forfeited, the Assyrians looked naively forward to the day when their wrongs would be righted ..." In what follows here, we do not see any naiveté. 
anxieties, miseries and dark future; because in Iraq we cannot live in any way. As our request is simple and we are a very small nation (or family), we trust that the British Government will take a kind action, and we shall be granted one of the two humble requests. We believe that our request will be heard and will receive a favourable [sic] reply. ${ }^{49}$

The main signatories of the petition were David d' Mar Shimun, Lady Surma, and twenty other tribes, which I quote in their original English spelling:

1. Mar Yosip Metropolitan of Shamsdinan, Tergawar \& Margawar; 2. Mar Zaya Serguis, Bishop of Jeloo, Baz and Beekon; 3. Lower Tiary; 4. Upper Tiary; 5. Thkoomar; 6. Jeloo; 7. Baz; 8. Deiz; 9. Gawar; 10. Shamsdinan; 11. Barwar; ${ }^{50}$ 12. Marbisho \& Eil; 13. Ttal; 14. AlBas, 15; Sarra-Mamidayee; 16. Timarydvan; 17. Noodez; 18. Leivon; 19. Guiramoon; 20. Barmayee d'Urmar.

This petition reached Geneva, but in April 1926 the file was noted "no action."51 Lack of available documentation makes it impossible for us to reconstruct the reaction of the unsuccessful petitioners. Apparently, no signs of protest followed.

Despite this will to emigrate, in 1926 the mandatory and Iraqi administration began to settle the Assyrian Christians in the northern part of Mosul province, close to Turkey. At the end of 1928, H.A. Foweraker, British Assyrian Settlement officer, reports about their situation:

The Assyrians have now grown accustomed to their situation in 'Iraq. Their relations with the officials of the 'Iraq Government are good and a number recently petitioned the Mosul liwa authorities stating that they wished in future to deal directly with the local officials without interference from their Patriarch, the Mar Shimun. Poverty no longer exists among them and through their thrift and the large pay derived from their employment in the Levies, they have become man for man more prosperous than their Kurdish, Yazidi, and Christian neighbours [sic]. The

49 UNOGL, LoN Archives, R610/11/50818/25888, Délimitation de la frontière entre la Turquie et l'Irak.

5o Those mentioned are Hassan Eshoo, Shamasha Salim, Yonan Hormizd, Syamoo Tooma, but not their chief, Mar Yalda Yawallaha, of whom we will hear in 1932.

51 UNOGL, LoN Archives, R610/11/50818/25888, Délimitation de la frontière entre la Turquie et l'Irak. 
fears of the Patriarchal Party are, however, being justified. As the Assyrians grow in prosperity and establish themselves in scattered villages, they are showing themselves more and more inclined to throw off the yoke of the Patriarchal authority, and Lady Surma is keeping the young Patriarch, Mar Shimun so jealously to her apron strings that he is losing prestige and touch with his peoples. ${ }^{52}$

Beside these internal leadership conflicts, which can be gathered also from other external sources, the almost treacherous tranquility described here did not last very long. It ended with the new Treaty of Alliance between Great Britain and Iraq of 30 June 1930, which was concluded in preparation for the termination of the mandate regime in Iraq in October 1932. But at the end of 1929, after the British and other supporters of the Assyrian Christians learned that this treaty did not contain clauses for minority protection, a storm broke out in London. Captain Anthony H. Rassam (1883-?), son of the well-known archaeologist Hormuzd Rassam (1826-1910), went to northern Iraq to collect fresh information on the ground. After his return, in June 1930, he founded the Iraq Minorities (Non-Moslem) Rescue Committee, ${ }^{53}$ and in September 1930 sent a voluminous petition of over eighty pages to Geneva, to which the previously mentioned Arnold T. Wilson made substantial contributions. ${ }^{54}$

Besides this short-lived committee of A. Rassam, ${ }^{55}$ we must mention two other important and well-established groups that advocated on behalf of Assyrian Christians. The first, founded in 1925, is the British Assyrians and Iraq Chris-

$5^{2} \quad$ FO 731/13027, Intelligence Report No. 25, 5 December 1928, para. 537, in Records of Iraq 1914-1966, vol. 5, ed. Alan de L. Rush (Slough: Archive Editions, 2001), 309.

53 The members of the committee were William Ch. Emhardt, Secretary of the Ecclesiastical and Racial Relations Commission of the Episcopal Church of America and of the Assyrian Relief Committee, George F. Gracey, Francis N. Heazell, W.B. Lane, Archibald H. Sayce, William A. Wigram, the Assyriologist David S. Margoliouth, Herbert W. Ward, Hugh Seymour Hall (treasurer), and E. Hollands (secretary). Initially, the committee was supported in part by the Archbishop of Canterbury, but he later distanced himself from A. Rassam.

54 UNOGL, LoN Archives, R2317/6A/22528/655 Jacket 4+5, Iraq. Situation of Assyrian Christians in Iraq.

55 After some further letters to Geneva and three appeals for donations (dated 31 January 1931, 17 August 1931, and $3_{1}$ October 1931), it seems that he refrained from further relief actions. Only the last appeal was published by Nelida Fuccaro, "An Appeal from The Iraq (nonMuslim) Minorities Rescue Committee, 1931," in The Modern Middle East: A Sourcebookfor History, ed. Camron M. Amin et al., (Oxford: Oxford University Press, 2006), 240-243. 
tians Committee ${ }^{56}$ and the second is the Iraq Committee ${ }^{57}$ of the League of Nations Union (LNU). Given the lack of research about their (common?) activities and overlapping memberships, at present no accurate conclusions are possible. Most probably, the Iraq Committee of the LNU came into existence during their collective efforts to safeguard minority rights in Iraq in the time after the termination of the mandate. The outstanding classical scholar Sir Gilbert Murray (1866-1957), chairman of the LNU, was deeply involved in this matter. In May 1931 he sent a draft declaration with suggestions for minority protection in Iraq, but unexpectedly refrained from pursuing his proposals just one month later. ${ }^{58}$ Nevertheless, his intervention succeeded: in May 1932 the Iraqi government was constrained to give a Declaration of guarantees before the Council of the LoN. ${ }^{59}$ It was the most comprehensive declaration ever given to Geneva: Nine of a total of sixteen articles concern issues of minorities (freedom of religion, cultural autonomy, etc.).

Mar Shimun Eshai and his supporters were alarmed by the upcoming termination of the mandate regime in Iraq. The political outlook to remain in Iraq without British protection opened a new round in their irreconcilable battle against the Iraqi government and their societal integration into the Iraqi state and society. After internal consultations, Mar Shimun Eshai sent petitions on 20 and 23 October $193^{1}$ to Geneva, in which he stated that it was impossible for them to live in Iraq without British protection. As before, in February 1926, he asked for the resettlement of Assyrian Christians outside Iraq, this time in a European country. ${ }^{60}$ However, again Mar Shimun Eshai's

$5^{6}$ By Leo S. Amery, Secretary of State for the Colonies (1924-1929), the befriended Henry S. Lunn (1859-1939), Methodist reverend, editor of the Review of the Churches and a forgotten transnational ecumenical figure. Its president was Randall Davidson, Archbishop of Canterbury (1903-1928).

57 In the 1930 s their members were Sir Gilbert Murray (president), Reginald M. Banks (House of Commons), Lord Willoughby H. Dickinson (British liberal parliamentarian and one of the founding leaders of the World Alliance for Promoting International Friendship through the Churches), Reverend Alan Don (as representative of the Archbishop of Canterbury), Martin (editor of the New Statesman and Nation), J. Gilbert Browne (brigadier of the Assyrian Levies in Irak (1925-1933)), Frederick Lugard (member of the Permanent Mandates Commission of the LoN), the aforementioned George F. Gracey, David S. Margoliouth, Ronald S. Stafford (former Administrative Inspector in Mosul), William A. Wigram, and Arnold T. Wilson.

58 UNOGL, LoN Archives, R2315/6A/21103/655, Mandate over Iraq. Cessation of the Mandate. Correspondence with various individuals and associations, 50.70-78.

59 LoN Official Journal, July (1932), 1347-1350 (A.17.1932.VII).

6 UNOGL, LoN Archives, R2318 Jacket6/6A/22528/655, Situation of Assyrian Christians in 
efforts were unsuccessful. In growing despair before October 1932 the patriarchal family, the Assyrian levies, and other tribal leaders reversed the migration plan of October 1931 and resorted to pressuring the British Mandate administration to grant their request for a homogenous "national" settlement. The Assyrian levies started a mutiny and announced that the termination of their military service for Great Britain would begin on 1 July 1932. Simultaneously, a "national" petition of 17 June 1932 was sent to Sir Francis Humphrys, British High Commissioner for Iraq (1929-1932). It comprised nine demands, including the official recognition of Assyrian Christians in Iraq as a "millet" (a separate nation), and not merely a racial or religious minority; the restitution of their former territories in the Hakkari region or, if this was not possible, the allocation of an autonomous territory in the Amadiya district (close to the Turkish border) with the recognition of Mar Shimun Eshai as temporal leader; financial compensation for lost church properties; political representation in the Iraqi House of Deputies; and the establishment of schools and a hospital. 61

In this crucial historical moment the faction opposed to Mar Shimun, usually silenced in the official historiography, also gained momentum. Mar Yalda Yawallaha of Barwari (1890-1950) and his supporters sent a counter-petition to the Iraqi government, and this was transmitted to the LoN. This small group of dissenters asked that the demands of Mar Shimun Eshai and his followers should not be considered, since they were aimed at "his own benefit and those of his relatives and friends" and this group asked that they be "permitted to live in peace and tranquility under the Iraqi flag." ${ }^{\prime 2}$ The commitment of the small tribe of Barwari Assyrian Christians to the Iraqi state and their resistance to the course of action of the patriarchal family and leading tribes can be explained, at least in part, by the fact that they had been settled in Iraq for a long time and had long considered it their homeland.

Neither the demands of Mar Shimun Eshai nor those of Mar Yalda Yawallaha of Barwari were fulfilled. Iraq gained full sovereignty on 3 October $193^{2}$ and became a member of the LoN. For Assyrian Christians this was the fulfillment of their political nightmare, i.e., Arab-Islamic rule without British protection.

Iraq, 5-6. The petition of 20 October $193^{1}$ (FO 371/16033) is published in Records of Iraq 1914-1966, vol. 6, ed. Alan de L. Rush (Slough: Archive Editions, 2001), 572.

61 It is published in Iraq Administration Reports 1914-1932, vol. 10, ed. Robert L. Jarman (Slough: Archive Editions, 1992), 475-476.

62 UNOGL, LoN Archives, R2318 Jacket6/6A/22528/655, C.P.M. 1298, Situation of Assyrian Christians in Iraq, 143-144. 
Their exasperation was enormous. Mar Shimun Eshai began a flood of petitions to the LoN; he resorted to the "sacred minorities' guarantees," as he called them once in a letter to Geneva (4 August 1933). At this point, the situation on the ground changed completely. Iraqi Kurdish armed forces attacked the rebellious tribes of Assyrian Christians, which began a collective move to the French mandated territory. The suppression of the rebellion got out of control and ended in a civilian massacre. After these traumatic events, for Assyrian Christians a life in "peace and tranquility" was no longer within the realm of possibility, rather a new protracted and exhausting stage of their concrete deterritorialization ${ }^{63}$ began; this did not end until their resettlement in Syria was brought to an end in 1937 .

In conclusion, this brief presentation of the LoN, A-Mandates, and the system of minority protection under international law reveals in Iraq a shared history. The political hopes for the national sovereignty of large parts of the Iraqi population hindered the wider understanding of A-Mandates as international administration and political trusteeship on behalf of the LoN against a much more familiar formula of British colonial rule. This uneasy situation, somehow "lost in translation" (P. Cox), did not find a political common ground during the twelve years of the mandate. The shared history of the LoN and Iraq was based rather on asymmetric entanglements, as the encounter of the frontier commission in 1925 and the mandatory declaration of guarantees of May $193^{2}$ show.

The system of minority protection under the guarantee of the LoN reveals further gaps in common ground. Iraqi Jews rejected it completely, while Assyrian Christians and their British advocacy groups used minority rights extensively for the preservation of their historical religious-political church organization in the new world order of nation-states. This history of the Assyrian Christians offers a unique example of the achilles heel of the system of minority protection of the LoN in limiting state sovereignty, and also generally in its entire history of minority protection. Even if the case of the tiny community of Assyrian Christians in Iraq is singular, it shows clearly, that without the LoN things would certainly have taken another course, as would their resettlement to Syria under the direct responsibility of the Council of the LoN. Thus,

63 That is to say, preparing the ideological de-territorialization in 1948, when Mar Shimun Eshai officially renounced his temporal powers over the ACE. See Heleen Murre-van den Berg, "Light from the East (1948-1954) and the de-territoritorialization of the Assyrian Church in the East," in Religion beyond its Private Role in Modern Society, ed. Wim K. Hofstee and Arie van der Kooij, International Studies in Religion and Society 20 (Leiden: E.J. Brill, 2013), 115-134. 
focusing on the LoN as an independent actor leads to a more comprehensive understanding of the history of Assyrian Christians of Iraq. This may be true of the broader Middle East, but this remains to be revealed.

\section{Primary Sources (unpublished)}

UNOG L, LoN = United Nations Office Geneva Library, League of Nations Archives R2315/6A/21103/655, Mandate over Iraq. Cessation of the Mandate. Correspondence with various individuals and associations.

R2317/6A/22528/655 Jacket 4+5, Iraq. Situation of Assyrian Christians in Iraq. R2318 Jacket6/6A/22528/655, C.P.M. 1298, Situation of Assyrian Christians in Iraq. R2318 Jacket6/6A/22528/655, Situation of Assyrian Christians in Iraq. R610/11/50818/25888, Délimitation de la frontière entre la Turquie et l'Irak. S14/D19, Assyriens. S345/No. 2/28-33, Iraq Minorities.

\section{Published Sources}

AIR 23/449. "The Residency Baghdad 4th August 1923 to Lady Surma Mar Shimun." In Bejtullah D. Destani (eds.), Minorities in the Middle East. Christian Minorities 1838 1967. Assyrian Communities in the Levant and Iraq, Part I, 1880-1938, vol. 7, Slough: Archive Editions, 2007, 208.

AIR 23/806, Secret Report. Appendix A: The Jews of Iraq, 9th July 1934. in Alan de L. Rush and Jane Priestland (eds.), Records of Iraq, 1914-1966, vol. 7. 629-635. Slough: Archive Editions, 2001.

American Jewish Committee. "Meeting of the Executive Committee," 14 February 1932, Rights of Minorities in Iraq, available online: www.ajcarchives.org, accessed January 2014.

Anonymous. "The Jews of Baghdad Petition for British Citizenship at the End of World War I," in Norman A. Stillman (ed.), The Jews of Arab Lands in Modern Times, 256258. Philadelphia: Jewish Publication Society, 1991.

An Assyrian Odyssey Covering the Journey of Kasha Yacoub Yauvre and his Wife Mourassa from Urmia to the Court of Queen Victoria 1879-1881 and The Exodus of Assyrians from their Ancestral Home 1918, comp. and annot. by Youel A. Baaba, Alamo: Youel A. Baaba Library, ${ }^{2}$ 2000, 81-132.

FO 731/13027, Intelligence Report No. 25, 5 December 1928. In Alan de L. Rush (ed.), Records of Iraq 1914-1966, vol. 5, 309. Slough: Archive Editions, 2001.

House of Commons on 20 February 1923 HC, Deb 20 Febr. 1923, vol. 161 cc2399-2471, also 
available online Hansard 1803-2005 http://hansard.millbanksystems.com/, accessed February 2014.

Iraq Administration Reports 1914-1932, vol. 10, 475-476. in Robert L. Jarman (ed.). Slough: Archive Editions, 1992.

L/P\&s/10/755, Self Determination in Iraq, English Text, Febr. 1919/Arabic Text, May 1919, 24.26/ Decl. No. 13 (5)-Baghdad; Decl. No. 14 (3)-Musul. In Robert L. Jarman (ed.), Iraq Administration Reports 1914-1932, vol. 3, 1-71. Slough: Archive Editions, 1992.

League of Nations. Declaration of the Kingdom of Iraq. (A.17.1932.VII), Official Journal, July (1932): 1347-1350.

League of Nations. Protection of Linguistic, Racial or Religious Minorities by the League of Nations. Resolutions and Extracts from the Minutes of the Council, Resolutions and Reports adopted by the Assembly, relating to the Procedure to be followed in questions Concerning the Protection of Minorities. (C.8.M.5.1931.I). Geneva: League of Nations ${ }^{2} 1931$.

League of Nations. Question de la frontière entre la Turquie et l' Irak. Rapport présente au Conseil par la Commission constituée en vertu de la résolution du 30 septembre 1924/Question of the Frontier between Turkey and Iraq. (C.400.M.147.1925.VII). Geneva: League of Nations 1924.

League of Nations. Ten Years of World-Cooperation. Geneva: League of Nations, 1930.

Mar Eshai Shimun. Light from the East. A Collection of 27 Issues from 1948 to 1954, Patriarchal Council, Inc. of the Church of the East, Chicago 2009.

Office of the Civil Commissioner. Memoranda on the Armenian and Assyrian Refugees at present in Camp Ba'qūba Mesopotamia. Baghdad: Government Press, 1919.

\section{Secondary Sources}

Anghie, Antony. "Colonialism and the Birth of International Institutions: Sovereignty, Economy, and the Mandate System of the League of Nations." International Law and Politics 34 (2002): 513-633.

Austin, Herbert H. The Baqubah Refugee Camp: An Account of Work on Behalf of the Persecuted Assyrian Christians. London, 1920 (repr. 2006).

Anonymous. The Assyrian Tragedy. Annemasse: Granchamp, 1934 (repr. 2010).

Bashkin, Orit. New Babylonians: A History ofJews in Modern Iraq. Stanford, cA: Stanford University Press, 2012.

Bell, Florence E.E.O. (ed.). The Letters of Gertrude Bell. London: Benn, 1927 (repr. Teddington, 2006).

Callahan, Michael. "Mandated Territories are not Colonies: Britain, France, and Africa in the 1930s," in R.M. Douglas (ed.), Imperialism on Trial: International Oversight of Colonial Rule in Historical Perspective, 1-20. Lanham, MD: Lexington Books, 2006. 
- Mandates and Empire. Brighton: Sussex Academic Press, 1999 (repr. 2008). . A Sacred Trust: The League of Nations and Africa. Brighton: Sussex Academic Press, 2004.

Cooper, Frederick and Ann L. Stoler. "Between Metropole and Colony: Rethinking a Research Agenda," in Frederick Cooper and Ann L. Stoler (eds.), Tensions of Empire: Colonial Cultures in a Bourgeo is World. Berkeley: University of California Press, 1997. Courtois, Sébastien de. The Forgotten Genocide: Eastern Christians, the Last Arameans. Translated by Vincent Aurora. Piscataway, NJ: Gorgias Press, 2004.

Fink, Carole. "The Minorities Question at the Peace Conference," in Manfred Boemeke, Gerald Feldman, and Elisabeth Glaser (eds.), The Treaty of Versailles: A Reassessment after 75 Years, 249-274. Washington, DC: German Historical Institute, 1998.

Housden, Martyn. The League of Nations and the Organization of Peace. London: Pearson, 2012.

Howe, Stephen. Anticolonialism in British Politics: The Left and the End of Empire, 19181964, Oxford Historical Monographs. Oxford: Clarendon Press Publisher, 1993.

Fisch, Jörg. Das Selbstbestimmungsrecht der Völker. Die Domestizierung einer Illusion. Munich: Beck, 2010.

Fisher, John. "Man on the Spot: Captain George Gracey and British Policy towards the Assyrians, 1917-45." Middle Eastern Studies 44, no. 2 (2008): 215-235.

Fuccaro, Nelida. "An Appeal from The Iraq (non-Muslim) Minorities Rescue Committee, 1931," in Amin Camron M. et al. (eds.), The Modern Middle East: A Sourcebookfor History, 240-243. Oxford: Oxford University Press, 2006.

Joseph, John. The Modern Assyrians of the Middle East: Encounters with Western Christian Missions, Archaeologists, and Colonial Powers. Studies in Christian Mission 26. Leiden: E.J. Brill, 2000.

Klinghammer, István and Gercsák, Gábor. "Der ungarische Geograph Pál Teleki als Mitglied der Mossul-Kommission." Cartographica Helvetica 19 (1999): 17-25.

Kovács, Péter. "Paul Teleki et le réglement de l'affaire de Mossoul dans la Société des Nations." Miskolc Journal of International Law 1, no. 2 (2004): 156-187.

The Protection of Minorities under the Auspices of the League of Nations, in Dinah Shelton, (ed.), The Oxford Handbook of International Human Rights Law, 325-344. Oxford: Oxford University Press, 2013.

Lenin. Collected Works. Translated by George Hanna. Moscow: Foreign Language Publishing House, 1965 .

Majd, Mohammad Gh. Persia in World War I and its Conquest by Great Britain. Lanham, MD: University Press of America, 2003.

Makko, Aryo. "Arbitrator in a World of Wars. The League of Nations and the Mosul Dispute, 1924-1925." Diplomacy \& Statecraft 21, no. 4 (2010): 631-649.

Malik, Yusuf. The British Betrayal of the Assyrians. Chicago: Assyrian National Federation, 1935 . 
Mar Aprem Mooken. The History of the Assyrian Church of the East in the Twentieth Century with Special Reference to the Syrian Literature in Kerala. Kottayam: St. Ephrem Ecumenical Research Institute, 2003.

Mar Shimun, Theodore d'. The History of the Patriarchal Succession of the D'Mar Shimun Family. Mar Shimun Foundation, ${ }^{2} 2008$.

McCarthy, Helen. The British People and the League of Nations: Democracy, Citizenship and Internationalism, c. 1918-45. Manchester: Manchester University Press, 2011.

Méouchy, Nadine and Peter Sluglett (eds.). The British and French Mandates in Comparative Perspectives. Social, Economic and Political Studies of the Middle East and Asia 93. Leiden: E.J. Brill, 2004.

Murre-van den Berg, Heleen. "Light from the East (1948-1954) and the De-Territoritorialization of the Assyrian Church in the East," in Wim K. Hofstee and Arie van der Kooij (eds.), Religion Beyond its Private Role in Modern Society, 115-134. International Studies in Religion and Society 20. Leiden: E.J. Brill, 2013.

Özcan, Mesut. "Border Concept and Turkey-Iraq Border." Turkish Review of Middle East Studies 13 (2002): 41-85.

Pedersen, Susan. "Back to the League of Nations." American Historical Review 112, no. 4 (2007): 1091-1117.

. The Guardians: The League of Nations and the Crisis of Empire. New York: Oxford University Press, 2015.

- "The Meaning of the Mandates System: An Argument." Geschichte und Gesellschaft 32 , no. 4 (2006): 560-582.

Scheuermann, Martin. Minderheitenschutz contra Konfliktverhütung? Die Minderheitenpolitik des Völkerbundes in den zwanziger Jahren. Materialien und Studien zur Ostmitteleuropa-Forschung 6. Marburg/Lahn: Herder Institute, 2000.

Schlaepfer, Aline. 'A Bagdad je resterai! Réception et diffusion du concept de 'nation' chez les intellectuels juifs de Bagdad entre la révolution jeune-turque et l' émigration (1908-1951)." PhD dissertation, University of Geneva, 2012.

Shields, Sarah. "Mosul, the Ottoman Legacy and the League of Nations." International Journal of Contemporary Iraqi Studies 3, no. 2 (2009): 217-230.

Stahn, Carsten. The Law and Practice of International Territorial Administration: Versailles to Iraq and Beyond. Cambridge Studies in International and Comparative Law. Cambridge: Cambridge University Press, 2008, 73-91.

Stillwell, Stephen J. Anglo-Turkish Relations in the Interwar Era. Studies in British History 73. Lewiston, NY: Mellen, 2003.

Thio, Li-ann. Managing Babel: The International Legal Protection of Minorities in the Twentieth Century. International Studies in Human Rights 81. Leiden: Nijhoff, 2005.

Travis, Hannibal. Genocide in the Middle East: The Ottoman Empire, Iraq, and Sudan. Durham, NC: Carolina Academic Press, 2010.

Trouillot, Michel-Rolph. Silencing the Past: Power and the Production of History. Boston: Beacon Press, ${ }^{6} 1995$. 
Weibel Yacoub, Claire. Surma l'Assyro-chaldéenne (1883-1975) dans la tourmente de Mésopotamie. Peuples et cultures de l'Orient. Paris: Harmattan, 2007.

Werda, Joel E. The Flickering Light of Asia, or the Assyrian Nation and Church. Chicago, 1924. (repr. 1990, 2011).

Winkler, Henry R. "The Development of the League of Nations Idea in Great Britain 1914-1919." Journal of Modern History 20, no. 2 (1948): 95-112.

. The League of Nations Movement in Great Britain 1914-1919. Rutgers University Studies in History 7. New Brunswick, NJ: Rutgers University Press, $195^{2}$ (repr. 1967).

Wright, Quincy. Mandates under the League of Nations. Chicago: University of Chicago Press, 1930 (repr. 1968).

Yacoub, Joseph. La Question Assyro-Chaldéenne, les Puissances Européennes et la Société des Nations (19o8-1938). Lyon: University of Lyon II, 1984. 